\title{
Analysis Of Economic Vulnerability Among Elderly Widows In Khyber Pakhtunkhwa, Pakistan
}

\author{
Hamid Alam \\ Department of Social Work \\ University of Peshawar \\ Basharat Hussain \\ Department of Criminology \\ University of Peshawar
}

\begin{abstract}
In Pakistani society, elderly widows usually face economic problems. Poverty is considered one of the prominent problems of elderly widows. They are lacking education, formal employment experience, modernization, old age pension and control over property which promote poverty among them. The attitudes of family and society are also not cooperative towards elderly widows which intensify their economic vulnerability. This study has been conducted in District Dir lower, Khyber Pakhtunkhwa. Sample frame was available in the form of a list of elderly widows in the office of Pakistan Bait Ul Mal, Dir lower. After exempting the young widows (having age less than 60 years) from the list, the respondents were selected randomly from the list. Data has been collected from the respondents through in-depth interviews. This study reveals that most of the respondents are illiterate and hence ineligible for formal sector employment. They also do not get old age pension. The respondents are also deprived of the right to property inheritance. They are dependent upon others for the fulfillment of their basic needs. Education, formal sector employment and right to property inheritance can alleviate the poverty of elderly widows.
\end{abstract}

Key words: Elderly Widows, Old Age Pension, Property Inheritance, Modernization, Economic Vulnerability.

$$
\begin{aligned}
& \text { تلخيص }
\end{aligned}
$$

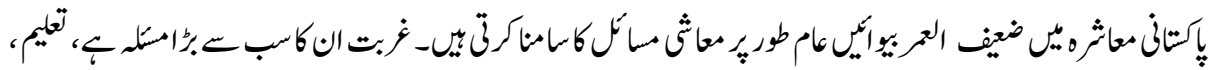

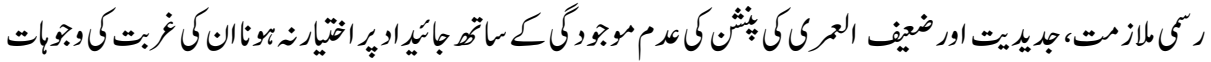

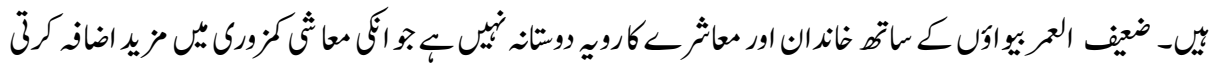

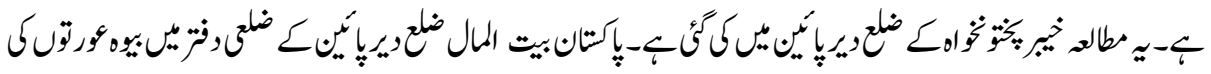

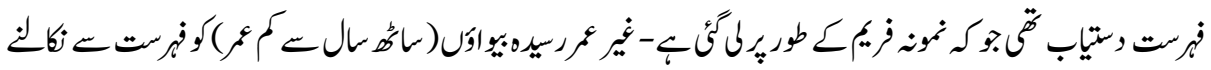

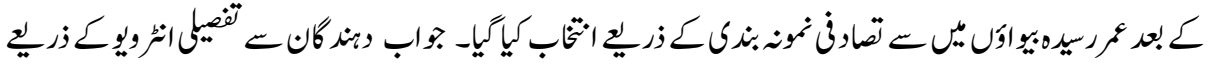

This work is Licensed under a Creative Commons Attribution-NonCommercial 4.0 International License (c) () () 


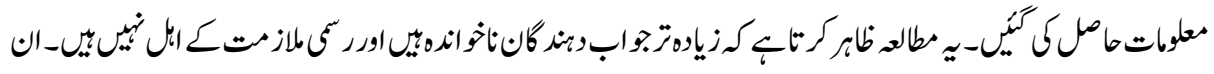

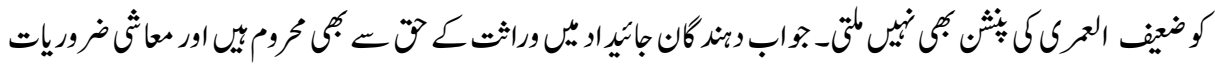

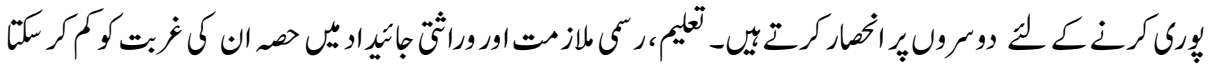

$$
\begin{aligned}
& -6
\end{aligned}
$$

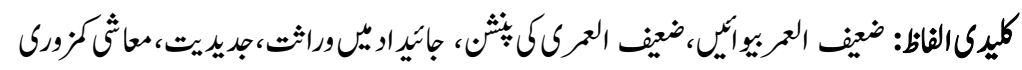

\section{Introduction}

All societies of the world consist of the population of ageing people, including elderly widows and widower (Begum, 2012; Nawaz, Maann, Akhter \& Ashraf, 2012). Generally, the population of elderly women is higher due to their higher life expectancy than men (Ehiemua, 2014). In most countries of the world elderly women outnumber the elderly men (United Nations, Department of Economic and Social Affairs, 2015).

In the context of Pakistani society also, the average life expectancy is higher for women i.e. 68.2 years for women, while 65.8 years for male, in 2017 (Government of Pakistan, 2017). As a result, widows constitute $8 \%$, while widowers constitute $3 \%$ of elderly population in Pakistan (Government of Pakistan, 2014). In 2012-13, the ratio of widowhood was $8.45 \%$. Among the provinces, the highest ratio of widows exists in Sindh province, where they constitute $8.70 \%$ of the total female population. After Sindh, Punjab is the second province having $8.64 \%$ population of widows, Khyber Pakhtunkhwa with $7.83 \%$, Balochistan with $6.48 \%$ widows' population (Sheikh, 2017).

In Pakistani society, not only the population of elderly widows is increasing, but the old age supporting culture is also on decline, which intensity their economic vulnerability. The elderly widows, on account of aging, face more challenges than elderly men. Mostly, the elderly widows face inequality, discrimination, poverty and abuse. Due to increasing population of elderly women and inequalities as well as discrimination, old age is now viewed from the feminine perspective. This phenomenon is known as the feminization of aging. Among the problems of elderly widows, economic hardships occupy a central position. Globally out of 245 million widows, 115 million live in extreme poverty (Widows rights international, 2010). Women, at their old age, are poorer than men particularly when women live without a partner as widowed, divorced/separated or never married (UNO, 2015; Sherlock, Corso \& Minicuci, 2015).

Holden and Kuo (1996) argued that men are supposed to be the breadwinner of the household, while women, usually, lack the earning experience and skills. After widowhood many elderly widows are, usually, unable to participate in income generating 
activities, therefore, face poverty. The economic impact of widowhood varies from bad to worst depending on the socio-economic status of the family (Nnodim, Albert \& Isife, 2012). In Pakhtun society, the household headship responsibility is usually managed by a male family member. However, when a woman becomes a widow, get divorce, separate or when the husband has migrated in search of employment, she has to shoulder the house management responsibility (Hasan, 2010; Javed \& Asif, 2011). Female household headship is viewed a challenging job particularly for elderly widows because it brings personal and familial problems for women (Hossain \& Huda, 1995). The major issue of female household headship is economic vulnerability. For financial management of the house, widows have to participate in income generating activities (Restrepo, 2002).

In developing countries, such as Pakistan, where the concept of social security and old age pensions is not developed, and the traditional family network has broken down, widows have few options of economic engagements. In some conditions, widows have to involve in the most exploitative and unregulated areas of informal sector labor. In addition, the possible employment opportunities, for elderly widows, may be domestic labor, and sending children to work as domestic servants or sacrificing them to early marriages (UNO, 2000; Nnodim, Albert, \& Isife, 2012).

Changing cultural values of Pakistani society also aggravated widowhood problems. Until recently, aging and widowhood was not an issue of the Pakistani society. Old age was considered an icon of honor, respect and wisdom. The reasons behind the high social status of elderly were considered to be the outcome of old age friendly socio-cultural factors including the popularity of joint family system and the prevailing social and religious values within society (Salahuddin \& Jalbani, 2006). However, due to changing socio-cultural values, the traditional social status of elderly.

In Pakistan, economic independence after retirement is enjoyed by limited number of senior citizens. Retirement funds are limited and government pension schemes are only for those who were employed in government sector jobs (Afzal, 1997). After retirement most elders are unable to find alternative sources of income and thus become largely dependent on their families for financial support. On one hand due to financial constraints, the government is unable to provide financial support to all senior citizens and on the other hand the values of the society regarding senior citizens are changing, which further intensify the miseries of senior citizens (Sabzwari \& Azhar, 2010). The vulnerability of many elderly people in Pakistan increased in recent years, particularly when their children themselves are too poor and over-burdened to care of their dependent parents (Sulman, 2008).

In Pakistan, most of women live below the poverty line because Pakistan is a developing country having low per capita income. Due to high inflation rate, unemployment, low literacy, cultural restrictions, patriarchal structure of the society, vulnerable poor 
including elderly widows are confronted with poverty (Tarar \& Pulla, 2014). In addition, the lack of old age pension schemes, deprivation of widows from property inheritance, economic dependence on children, weak employment, financial background of deceased husband and disintegration of joint family system are considered responsible for widows' poverty in Pakistan (Arif \& Farooq, 2012).

\section{Objectives of the Study}

The objectives of this research study are to

1- To study the impact of property inheritance on elderly widows economic life

2- To dig out the economic impact of old age pension on the lives of elderly widows

3- To know the role of Pakhtun cultural practices about elderly widows' poverty

\section{Review of Literature}

Several factors are considered responsible for elderly widow's poverty. The first major factor is personal characteristics (lack of education, knowledge, experience and employment skills) that appear to be associated with widow's poverty. Such personal characteristics of elderly widows are viewed to be the outcome of discriminatory socialization of female children. Due to discriminatory socialization, women generally accumulate less knowledge and experiences in instrumental skills than men, which cause poverty among them at their old age (Lopata, 1973; Tarar \& Pulla, 2014).

In patriarchal societies the education of male is preferred over the female. The family invests its resources on the education of male child while the education of girls is usually ignored (Loomba Foundation, 2015). Globally, 781 million people, having age 15 years and above, are illiterate. Illiteracy rate is highest among older people, and is higher among women than men. Worldwide $30 \%$ women and 19\% men senior citizens are illiterate (UNO, 2015). According to Pakistan Social and Living Standards Measurement survey (2015), the literacy rate for male was 70\%, while for female it was $49 \%$ (Government of Pakistan, 2016).

As a result, of early life deprivations and gender imbalance, women lack employment skills, and are economically dependent on their husbands and earning children. In addition, gender disparities, in economic power-sharing also contribute toward the elderly widows' poverty.

Cultural factors also play role in elderly widow's poverty. Women, in rural areas, face restrictions on employment on account of their gender. In Pakistani society, due to cultural barriers, more women are unemployed and resultantly poor. These difficulties include the burden of domestic work and the responsibility of household headship 
particularly in the case of widows with young children and limited access to institutional credit (Chen \& Dreze, 1995). Labor Force Survey (2014-15) reported that the participation of men in labor force was $48.0 \%$ in 2014 and $48.1 \%$ in 2015, while for female labor force participation was $15.8 \%$ in 2014 and $15.8 \%$ in 2015 (Government of Pakistan, 2015). The employment and economic status of elderly widows are closely interlinked. Choudhury \& Leonesio (1997) argued that the economic hardships of those elderly widows are more severe who have never participated in income generated activities themselves, or whose husband's earning was not attractive. In addition, cultural norms associated with widowhood, also leads to a number of practices, including denial of inheritance, limited mobility outside the house and limited economic and social participation, which further leads to further poverty among elderly widows (Sherlock, Corso \& Minicuci, 2015).

Other socio-cultural factors such as change from joint to nuclear family structure, economic dependence on children, loss of authority and changing old age supporting values are also considered the causes of elderly widow's poverty (Alam, Ibrar \& Khan, 2016).

\section{Lack of Old Age Pension and Elderly Widow's Poverty}

In Pakistan, the ageing population having poverty as a major issue is increasing but there is lack of old age pension (Kamal \& Woodbury, 2016). Old age pension aims to support individuals, who are unable to earn a living in later life (Wahab, Mufti \& Khan, 2017). In Pakistan, about 0.85 million retired employees get old age pension of the total aged people of over seven million (Ashiq \& Asad, 2017). A very large section of the ageing female population is pension less because they face hurdles to get pensionable government employment due to less education, limited employment opportunities and cultural restriction of veil (Kamal \& Woodbury, 2016). Due to poverty and lack of pension, poor elderly widows usually look toward charity. In Pakistani society, the major source of economic assistance for elderly widows is charity offered by the society. It has been estimated that in Pakistan, 100-120 billion rupees (equal to $2 \%$ of Pakistan GDP) are donated privately, for welfare activities (Hasan, 2010).

Nature of employment also affects the old age pension of elderly widows. Majority of the workforce, particularly women are involved in the informal economy during their young age. In informal economic system, the concept of old age pension is lacking (Nasir \& Ali, 2000).

In Pakistan majority of elderly women lack their own old age pension, however, the widow of a retired government servant can get old age pension in the name of family pension. The widow (s) of a deceased government employee is eligible for family 
pension (Government of Pakistan, 2006). In addition, the widows of lower paid government employees also receive a one-time grant for rehabilitation from the official Benevolent Fund. In the private sector employment the concept of economic security of deceased employee is usually lacking. On the basis of philanthropy and humanity some short term assistance may be probably provided (Hasan, 2010).

Old age pension is considered a shield against old age poverty. However, those widows and other senior citizens, who are getting old age pension, also face economic problems. The old age pension, received by the senior citizens, is usually insufficient to cover the inflationary effects and fulfill their economic needs. Most of the pensioners, therefore are economically dependent on their children or other relatives (Salahudin \& Jalbani 2006).

\section{Deprivation from Property Inheritance Accelerates Elderly Widows' Poverty}

Transfer of wealth and property in the form of inheritance from one generation to another, provides an important source of economic security, particularly at old age. The practice of property inheritance is of paramount importance in poor countries, where formal social security networks are usually lacking (Ahmad, Bibi \& Mahmood, 2012). Moreover, property possession may also affect the living arrangements of elderly people. In developing countries the hope of children for parental inheritance motivates them to live with them at their old age. The elderly from households with larger land holdings tend to live with their children, while those parents having no or less land tend to live separately from their children (Petri, 1982).

Property inheritance may help in successful ageing, however, women especially widows face deprivation from inheritance in property. Male members of the deceased husband's family compel the widows to withdraw from the family home and even cooking utensils of the house (Loomba Foundation, 2015). In some parts of the world an important reason for excluding women from the right of their inheritance is that they are regarded as part of the estate to be transferred to heirs, in accordance with the regular rules of inheritance. In this regard, in Africa, Wales, Athens, Hindus (Aryan type family system), Arabia and Israel (during nomadic stage) the independent status of women was not recognized at all (Zehra, 2007).

In Pakistani society also, elderly widows are usually deprived of their inheritance, in parental and husband's property. According to International Property Rights Index 2008, Pakistan has been ranked 93rd out of 115 regarding the protection of property rights. Many women of feudal families in interior Sindh, Southern Punjab, some parts of Khyber Pankhtunkhwa and Baluchistan are not allowed to enter into marriage as result of the fear of women demand in property inheritance (Rehman, 2010). Although, majority of Pakistani population consists of Muslims and Islam gives the right of inheritance to 
women also (Rehman, 2010). Regarding the right to inheritance of women Quran says "For men there is a share from what their parents and close relatives leave, and for women there is a share from what their parents and close relatives leave, be it little or considerable; a definite share" (Surah Nisa' 4:7). In addition to religion, the constitution of Islamic Republic of Pakistan and Muslim inheritance laws guarantee the right to property inheritance (Zehra, 2007).

The religion as well as constitution of Pakistan grants the right of inheritance to women. However, the cultural practices, the materialistic attitude of male family members, the defective legal system and lack of awareness among women regarding property legal proceedings and property rights and women's mobility restrictions create hurdles for women to get their legal share in property (Muhammad, 2011; Ahmad, Bibi \& Mahmood, 2012). Detailed and reliable data regarding women's ownership of land/property is lacking in Pakistan. However, Rehman (2010) cited the report of National Commission on Status of Women that only 3\% women in Pakistan get inherited properties/lands.

The patriarchal system in Pakistani society creates hurdles in the way of women to their share in property inheritance. The patriarchal system, favor sons to enjoy the right of receiving almost all the assets left by their parents, while daughters generally do not receive or are obliged to surrender from their legal share in property inheritance. Women are often expected to withdraw from their rights to inheritance in favor of their brothers. Dowry, received by daughters, at the time of marriage is considered a substitute of property to be inherited. Moreover, women are told that their brothers will take care of them, and the gifts given to them on different occasions are considered their share in property (Ahmad, Bibi \& Mahmood, 2012). Moreover, if a woman files case in a court of law for property inheritance, then she is motivated by family members to withdraw her case, because the demand of women for property inheritance is considered condemnable and can lead to social boycott, physical torture and even death of women (Zehra, 2007). According to a report, a woman in Punjab province of Pakistan filed a suit in a court of law for inheritance in parental property. The court decided the case in favor of the woman. When the women tried to take the possession of the property, her brothers tortures her physically and ultimately led to fractures in her both legs (Pakistan Today, April 07, 2018).

Those women, who receive share in property inheritance, are usually not the actual owner of this property. According to Kamal (1999) male relatives often have control over the property even where women are the actual owner of property. Often, women cannot dispose of their property without the household consent. Only male members of the family are authorized to buy and sell property. In several cases, where women's names are registered in the property transfer papers on inheritance, women in practice cannot get the property and its control. In Pakistani society, property is, usually, in the control of the 
brothers, while sisters can get their share in the production/income of the property (Ahmad, Bibi \& Mahmood, 2012).

\section{Modernization a Cause of Elderly Widows' Poverty}

According to modernization theory of ageing, the process of modernization makes it difficult for elderly people to employ their traditional earning skills. They are unable to play roles which they once played in the traditional societies (Abanyam, 2013). Technological progress has reduced the opportunities of meaningful employment and roles for elderly widows. Due to the process of modernization, the elderly widows have either abolished their traditional roles or their roles have been greatly reduced in significance (Jacobsen, 2011). The introduction of printing press is an example of technological development which reduced the traditional role of cultural transmission to young generation by elderly people (Branco \& Williamson, 1982).

Modernization also creates generation gap. In past when modernization was lacking the relation the care of parents was considered the responsibility of children. However after modernization and technological development children usually do not care regarding parental respect. Today parents and older people can only give guidance, and now it depends upon children either to accept or reject it (Cole \& Durham 2007).

Modernization also brought other socio-cultural changes in the form of family nuclearization, economic independence of young generation, decline of old age supporting values which adversely affected the socio-economic status of elderly population (Rehman \& Mohyuddin, 2015).

\section{Research Methodology}

Qualitative methodology has been used for this research study because qualitative research focuses on the experience or data which cannot be explained numerically (Hancock, Ockleford \& Windridge, 2009). This research study also aims to identify the implication of economic problems for elderly widows, which may be described and cannot be quantified.

List of widows has been collected from the office of Pakistan Bait-ul-Mall, District Dir lower. The list consisted of widows having different age groups. Widows below the age of 60 years have been exempted from the list. Respondents (having age 60 and above) have been selected randomly from the list. The Pakhtun cultural norms do not allow a male researcher to collect data from female respondents. So the services of female research assistant were hired for data collection after the necessary training. Data was collected from the respondents in their houses through in-depth interview because this 
tool of data collection provide flexible environment to the respondents, particularly to the illiterate respondents to express in detail the reason of their economic vulnerability.

\section{Results and Discussion}

\section{Personal Factors Responsible for Elderly Widows’ Poverty}

The participants were investigated regarding the reasons of their poverty. During data collection it was found that two factors were responsible for widow's poverty i.e. personal factors and socio-cultural factors. The elderly widows who lack personal earning skills (education, technical and vocational skills) were poor. In addition, the respondents who have been deprived of the financial benefits of the deceased husband also faced poverty.

Regarding the impact of widowhood on economic status a respondent said that

"Widowhood has brought a number of problems for me but the central problem is poverty"

Regarding the personal factors of elderly widows' poverty another respondent reflects that

"I am facing poverty after widowhood because I cannot earn due to my old age and illiteracy"

The impact of illiteracy on women's employment, and resultant poverty can be observed at the national level also. In Pakistan, women constitute $46 \%$ of the total population, but constitute only $29 \%$ of the labor force due to their illiteracy. Only $5.4 \%$ women earned from government jobs (Mahbub-ul-Haq Human Development Center, 2000). However, when a woman becomes divorcee or widow, it compels her to participate in income generating activities, in order to fulfill her own and children's needs (Ferdoos, 2006). Due to illiteracy and lack of jobs, women are usually unable to find proper job. Usually the poorest women get engaged in lowest paid jobs (Kazi, 1999). Such lowest minor jobs include cloth washing and pitching water, cooking and general cleanliness in some one's house. Chaudhry (2004) also found that women from the respectable families remain busy in their domestic chores and serve their husbands and children. While women of the lower class, such as widows come to their houses and help them in their house management.

In this regard, a respondent said

"My family members are unable to fulfill my needs, but they do not like my employment in someone house. It is considered a stigma in our family to work in someone house at domestic labor." 
Such women have to work for long hours at minimum wages with no medical benefits, child care support or retirement benefits. Domestic work is often one of the jobs available to women, but most employers will not let women keep their children with them. Many widows have to put their children into orphanages when they migrate to cities in search of work (Chen \& Dreze, 1995).

The analysis of collected data shows that during young age rural women had been working in agriculture sector. Isran \& Isran, (2012) also found that these women shouldered different agricultural activities. Almost $80 \%$ rural women make contribution in agricultural sector; however, majority of rural women are considered unpaid family workers As a result, women have no source of personal income, and are dependent upon family members, for the fulfillment of their needs.

Socio-cultural factors are also considered responsible for elderly widow's poverty. In Pakhtun culture women face different hurdles which cause poverty among them. Purdah (veil) is considered to create hurdles in the way of women's education and employment. Moreover, parents prefer the education of son(s) because in Pakhtun culture men are considered responsible for bread winning responsibility. Parents usually avoid to send their daughters to educational institutions at the cost of violation of purda. Girls are allowed to get education and learn the earning skills in feminine environment. Similarly the practice of purda is considered responsible for low economic and employment participation. Qualified women prefer to avail employment in health department as a Doctor and in education department as teacher, where they can easily manage their purdah. In rural areas paid work of women, particularly low income job outside the house is considered undesirable due to purda. Usually the poorest women get engaged in lowest paid jobs (Kazi, 1999). Lack of education and employment participation cause poverty among them at their old age.

\section{Old Age Pension and Economic Status of Elderly Widows}

The universe of this study is a rural area, where limited job opportunities are available. In addition, most of the respondents were illiterate because the residence of the respondents was a part of the state of Nawab (Duke) Dir. The District Dir has been amalgamated into Pakistan in 1960. The Nawab (Duke) was against modern education and therefore, he did not build any school or college. Those who were interested in receiving education, they were exiled from the state (Shah, 2013). Majority of the respondents commented that at the time of their school going age, no school was there. Moreover, female education was condemned by the society. As a result of respondents' illiteracy, they were unable to get formal sector employment, and hence lacked old age pension.

Some of the respondents of this research study got the family pension of their deceased husbands. The respondents, whose husbands were retired from government serviced, 
receive family pension. However, the economic problems of those respondents were more severe, who were lacking family pension and were dependent upon other for the fulfillment of their basic needs.

In rural areas of Khyber Pakhtunkhwa there are limited private sector employment opportunities as well as awareness regarding the institutions which are working for old age pension. For example, the Government of Pakistan has established Employees Old age Benefit Institution. An insured worker who employed in private sector is eligible for old age pension under the EOBI pension scheme. However, due to lack of awareness very few people know about this institution.

\section{Property Inheritance and Elderly Widows' Poverty}

In response to a question regarding property management and its impact on the socioeconomic status on elderly widows, most of the respondents commented that male family members control the property, if property is there. Deprivation from property inheritance brought adverse economic impact for all respondents, particularly those who shared house management responsibility.

Regarding inheritance in property only one respondent had inherited her share (as a wife) in property. The respondents who had not inherited their share in property, either property was lacking or the male family members were not ready to grant it to women. In this regard, a respondent says:

"I am litigating with my brother on my share in parental property. I am poor, and he is not ready to give me my share in parental property."

In Pakistani society, women are legally allowed to have access to family wealth. However this practice is rarely exercised in Pakistani society. The situation regarding women property inheritance is particularly alarming in rural Pakistan. The tribal nature of rural society undermines women's inheritance rights (Ahmad, Bibi \& Mahmood, 2012).

Other respondents mentioned various reasons of deprivation in property inheritance. Important reasons were lack of awareness, demand of property inheritance disturb family social relations, and expensive/lengthy process of litigation over property. Ahmad, Bibi and Mahmood (2012) argued that women are said to have lack of information about legal and economic rights. An important barrier for women is their lack of knowledge about their property rights and limited understanding of land registration systems, transaction procedures and other legal matters, involved in possession of land. They are also considered to have restricted mobility. 
According to the respondents, if they get and sell the property, it can alleviate their poverty, however, they do not demand inheritance in parental property due to poverty of their parents and brothers.

\section{Modernization and Elderly Widow's Poverty}

Modernization theory of ageing believes that the process of modernization brings problems for the elderly population. On one side, modernization causes improvement in the average life expectancy while on the other hand modernization brings changes which are considered unfavorable for successful ageing process. Although Pakistani society is still considered traditional in nature, however, some socio-cultural changes took place in Pakistani society, are considered the outcome of modernization. Such changes took place in the form of breakdown of joint family and formation of nuclear family, decline of old age supporting cultural and religious values, materialistic attitudes of young generation and formal employment activities of young qualified women. These changes created various socio-economic problems for elderly women.

\section{Conclusions}

In traditional societies, the culture usually favors the elderly population including widows. There are old age supporting values in the form of joint family system, strong hold of social and religious values. As a society changes from traditional toward the modernity, it leads toward the economic vulnerability of elderly widows because they are unable to make adjustment with the changing socio-economic scenario. They lack education, employment skills, property and other form of economic security at old age. On one side, they lack the economic potentials, and on the other hand, the old age supporting values also disappear. This entire situation leads to the economic vulnerability of elderly widows.

\section{Recommendations}

- In order to improve the economic status of elderly widows in Khyber Pakhtunkhwa, the following points are recommended

- To provide education to girls during their school going age.

- To provide opportunities to elderly widows to exercise their learned traditional earning skills.

- To create awareness among women regarding their right of property inheritance.

- To promote religious motivation among men to grant women the Islamic right of property inheritance in property.

- To establish free legal aid centers to assist elderly widows to get their right to property. 
- To promote the concept of women employment according to the norms of Pakistani culture.

- To promote the concept of compulsory old age pension.

\section{References}

Abanyam, N. L. (2013). The Changing Privileges and Challenges of Older People in Contemporary African Society. Global Journal of Art, Humanities and Social Sciences, 1(4), pp.34-43.

Afzal, M. (1997).Population ageing issues in Pakistan: A further analysis, some problems and issues of older persons in Asia and Pacific. New York: United Nations (ESCAP Asian Population Studies 11), pp.44-80.

Ahmad, E., Bibi, A. \& Mahmood, T. (2012). Attitudes towards Women's Rights to Inheritance in District Lakki Marwat, Pakistan. The Pakistan Development Review, pp.197-217.

Alam, A., Ibrar, M., \& Khan, P. (2016). Socio-Economic and Psychological Problems of the Senior Citizens of Pakistan. Peshawar Journal of Psychology and Behavioral Sciences (PJPBS), vol.2:2, pp.249-261.

Arif, G. M. \& Farooq, S. (2012). Dynamics of Rural Poverty in Pakistan: Evidence from Three Waves of the Panel Survey. Pakistan Institute of Development Economics, Islamabad.

Ashiq, U. \& Asad, A. Z. (2017). The Rising Old Age Problem in Pakistan. Journal of the Research Society of Pakistan, 54(2), pp.325-333.

Begum, F.A. (2012). Ageing, Discrimination and Older Women's Human Rights from the Perspectives of CEDAW Convention. Available online at: http://www.ngocoany.org/perspective_human_rights.pdf. [Accessed on 2018, April 10]

Branco, K. J. \& Williamson, J. B. (1982). Stereotyping and the Life Cycle: Views of Aging and the Aged.In the Eye of the Beholder: Contemporary Issues in Stereotyping, vol.4:7, p.364.

Chaudhry, L.N. (2004). Women and Poverty: Salient Findings from a Gendered Analysis of a Quasi-Anthropological Study in Rural Punjab and Sindh. Sustainable Development Policy Institute, Islamabad. 
Chen, M \& Dreze, J. (1995). Recent Research on Widows in India Workshop and Conference Report. Economic and Political Weekly. pp.2435-2450.

Choudhury, S. \& Leonesio, M.V. (1997). Life-Cycle Aspects of Poverty among Older Women. Available online at https://books.google.com.pk/books?hl=en\&lr=\&id= YSFYAAAAYAAJ\&oi $=$ fnd $\& p g=$ PA $1 \& d q=$ Choudhury,+ S $.+\% 26+$ Leonesio,$+\mathrm{M}$. V.+(1997).+Life-Cycle+Aspects+of+Poverty+among+Older+women.+Soc.+Sec. + Bull., $+60,+17 . \& o t s=$ SiIesV0-4G\&sig=1gJRWe-_xrqnvQbR0U_uixtZyFA\#v= onepage \&q\&f=false

Cole, J. \& Durham, D.L. (2007). Generations and Globalization: Youth, Age, and Family in the New World Economy (Vol.3). Bloomington: Indiana University Press.

Ehiemua, S. (2014). Gender Longevity: Male/Female Disparity. International Journal of Academic Research and Reflection, vol.2:3, pp.32-38.

Ferdoos, A. (2006). Social Status of Rural and Urban Working Women in Pakistan- A Comparative Study (PhD Dissertation). Universität Osnabrück, Mülheim. Available online at: https://d-nb.info/980210313/34 [Accessed on 2018, August 24]

Government of Pakistan. (2006). Finance Division and office of the Accountant General of Pakistan \& Pakistan Public Administration Research Centre of Establishment Division. A Manual of Pension Procedures. Available online at: http://www.agpr.gov.pk/download/A\%20Manual\%20on\%20Pension\%20Procedur es\%20(NEW).pdf [Accessed on 2019, July 20]

Government of Pakistan. (2014). Pakistan Bureau of Statistics. Compendium on gender statistics of Pakistan 2014 available online at: http://www.pbs.gov.pk/sites/ default/files/social_statistics/publications/compendium_on_gender_statistics_of_p akistan_2014.pdf [Accessed on 2018, January 22]

Government of Pakistan. (2014-15). Pakistan Bureau of statistics. Labor force survey 2014-15 Thirty-third issue. Available online at: http://www.pbs.gov.pk/content/ labour-force-survey-2014-15-annual-report [Accessed on 2018, May 8]

Government of Pakistan. (2016). Pakistan Bureau of Statistics, Pakistan Social and Living Standards Measurement Survey (2014-15) available online at: http://www.pbs.gov.pk/sites/default/files/pslm/publications/PSLM_201415_National-Provincial-District_report.pdf [Accessed on 2019, August 21] 
Government of Pakistan. Department of Finance. (2017). Population, Labor Force and Employment, Chapter 12. Available online at: http:/www.finance.gov.pk/survey/ chapters_17/12-Population.pdf [Accessed on 2018, July 12]

Hancock, B., Ockleford, E. \& Windridge, K. (2009). An Introduction to Qualitative Research. Trent Focus Group, Nottingham.

Hasan, M. (2010). Conditions of Widows in Pakistan. Pakistani Law and Democracy. Available online at: https://mazdoorkissan.wordpress.com/2010/11/16/conditionof-widows-in-pakistan/ Accessed on 2018, May 18.

Holden, K.C. \& Kuo, H. D. D. (1996). Complex Marital Histories and Economic Wellbeing: The Continuing Legacy of Divorce and Widowhood as the HRS Cohort Approaches Rretirement. The Gerontologist, vol.36, pp.383-390.

Hossain, M. Z. (2012). Zakat in Islam: A Powerful Poverty Alleviating Instrument for Islamic Countries. International Journal of Economic Development Research and Investment, vol.3:1, pp.1-11.

Jacobsen, J. P. (2011). The Role of Technological Change in Increasing Gender Equity with a Focus on Information and Communications Technology. ACSPL Working Paper Series, vol.1:1, p.2.

Javed, Z. H., \& Asif, A. (2011). Female households and poverty: A case study of Faisalabad District. International Journal of Peace and Development Studies, vol.2:2, pp.37-44.

Kamal, A. \& Woodbury, L. (2016). Emerging Opportunities for Women in Khyber Pakhtunkhwa Growth Sectors Industry. Available online at: https://www.theigc.org/wp-content/uploads/2016/04/Kamal-Woodbury-2016Working-paper.pdf [Accessed on Accessed on 2019, March,7]

Kamal, S. (1999). Effects of the Interplay of Formal and Customary Laws on Women in Tribal Cultures. Paper Presented at the $7^{\text {th }}$ Interdisciplinary Congress on Women, Women's Worlds, 1999, Norway, Tromso.

Kazi, S. (1999). Gender Inequalities and Development in Pakistan, in Shahrukh Rafi Khan, ed. 50 Years of Pakistan's Economy: Traditional Topics and Contemporary Concerns. Karachi: Oxford University Press, pp.376-414. 
Petri, P.A. (1982). Income, Employment and Retirement Policies. In International Perspectives on Aging: Population and Policy Challenges. R.H. Binstock et al., eds. New York: United Nations Fund for Population Activities.

Sherlock, L., P., Corso, B. \& Minicuci, N. (2015). Widowhood, Socio-Economic Status, Health and Wellbeing in Low and Middle-Income Countries. The Journal of Development Studies, vol.51:10, pp.1374-1388.

Loomba Foundation (2015). The Global Widows Report. Available online at Available at http://www.theloombafoundation.org/images/The\%20Global\%20Widows\%20Re port\%202015.pdf [Accessed on 2018, February 23].

Lopata, Z.H. (1973). Self Identity in Marriage and Widowhood, The Sociological Quarterly, vol.14:3, pp.290-439.

Mahbub-ul-Haq Human Development Center (2000) Human Development in South Asia, The Gander Question; Karachi, oxford University Press.

Muhammad, N. (2011). Inheritance in Property: A Gender Based Discriminatory Practice in Rural Areas of Tangi, District Charsadda. Sarhad J. Agric. Vol.27:1, pp.143-146.

Nasir, Z.M. \& Ali, S.M. (2000). Labor Market Participation of the Elderly. The Pakistan Development Review, vol.39:4, pp.1075-1086.

Nawaz, N., Maann, A.H., Akhter, S. \& Ashraf, I. (2012). Status of Elderly Women in Socio-Economic and Cultural Context in Punjab, Pakistan. Sarhad J. Agric, vol.28:2, pp.373-378.

Nnodim, A., Lbert, C. \& Isife, B. (2012). The Effect of Widowhood on the Income Generation and Well-Being of Rural Women in Rivers State, Nigeria. Developing Country Studies, vol.2:11, pp.135-143.

Pakistan Today. (2018, April, 7). Khanewal Brothers Allegedly Cut off Sister's Legs Over Property Dispute. Available online at: https://www.pakistantoday.com.pk/2018/ 04/07/khanewal-brothers-allegedly-cut-off-sisters-legs-over-property-dispute/ [Accessed on 2018, September 24]

Rehman, I. \& Mohyuddin, A. (2015). Social Issues of Senior Citizens. The Explorer Islamabad: Journal of Social Sciences, vol.1:8, pp.301-306. 
Rehman, S. (2010). Denial of women's rights of inheritance: Enhancing their vulnerability and domestic \& societal violence. Awaz Foundation Pakistan: Centre for Development Services. Available online at: http://awazcds.org.pk/ Downloads/rstudies/Inheritance\%20Rights.pdf [Accessed on 2018, March 3]

Restrepo, R. J. (2002). Female-headed households and their homes: The case of Medellin (Master thesis) McGill University, Canada.

Sabzwari, S. R. \& Azhar, G. (2010). Ageing in Pakistan-A New Challenge Ageing. Ageing International, vol.36:4, pp.423-427.

Salahuddin, K. \& Jalbani, A. A. (2006). Senior Citizens: A Case Study of Pakistan. Journal of Independent Studies and Research (JISR), vol.4:2, pp.26-31.

Shah, G. A. (2013). Administration of Dir Under Nawab Shah Jehan. Pak Ann Res J, vol.49, pp.121-138.

Sheikh, M. A. (2017). International Widows Day. World Time. Available Online at: http://jworldtimes.com/jwt2015/magazine-archives/jwt2017/jun2017/international -widows-day/ [Accessed 2017, December 12]

Sulman, N. (2008). The Situation of Elderly Population in Pakistan: Problems and Prospects. Pakistan Journal of Special Education, vol.11:2, pp.01-23.

Tarar, M. G. \& Pulla, V. (2014). Patriarchy, Gender Violence and Poverty amongst Pakistani Women: A Social Work Inquiry. International Journal of Social Work and Human Services Practice, vol.2:2, pp.56-63.

United Nations Children's Emergency Fund (2000). Domestic Violence against Women and Girls. Available Online at: https://www.unicef.org/malaysia/id_2000_ domestic_violence_women_girls_6e.pdf [Accessed on 2019, April 6]

United Nations, Department of Economic and Social Affairs (2015). The World's Women 2015, Trends and Statistics, Chapter 8. Available online at: https://unstats.un.org/ unsd/gender/downloads/WorldsWomen2015_chapter8t.pdf [Accessed on 2019, August 16]

Wahab, M., Mufti, O. \& Khan, M. A. (2017). The Effects of Population Ageing on the Public Pension System in Pakistan. Abasyn University Journal of Social Sciences, vol.10:2, pp.252-269. 
Widows Rights International (2010). The Challenges Faced by Widows. Available Online at: https://www.widowsrights.org/researchdocumentkbrewerr0911.pdf [Accessed on 2019, November 25]

Zehra, A.S. (2007). National Commission on the Status of Women. Annual Report 2007, Available online at: https://www.ncsw.gov.pk/previewpublication/12 [Accessed on 2019, May 23].

Hamid Alam is Ph.D Scholar in the Department of Social Work, University of Peshawar, Khyber Pakhtunkhwa, Pakistan.

Dr. Basharat Hussain is Professor in the Department of Criminology, University of Peshawar, Khyber Pakhtunkhwa, Pakistan. 